University of Wollongong

Research Online

Faculty of Engineering and Information

Faculty of Engineering and Information

Sciences - Papers: Part A

Sciences

$1-1-2015$

\title{
Goal-driven context-aware data filtering in loT-based systems
}

Nanjangud C. Narendra

MS Ramaiah University of Applied Sciences, Bangalore, narendra@in.ibm.com

Karthikeyan Ponnalagu

University of Wollongong, kp946@uowmail.edu.au

Srikanth Tamilselvam

IBM Research India

Aditya Ghose

University of Wollongong, aditya@uow.edu.au

Follow this and additional works at: https://ro.uow.edu.au/eispapers

Part of the Engineering Commons, and the Science and Technology Studies Commons

Research Online is the open access institutional repository for the University of Wollongong. For further information contact the UOW Library: research-pubs@uow.edu.au 


\title{
Goal-driven context-aware data filtering in loT-based systems
}

\begin{abstract}
One of the crucial research issues in an loT-based system is how to manage the huge amount of data transmitted by the potentially large number of sensors that form the system. Prior research has focused on centralized cloud-based 'Big Data' architectures for collecting, collating and analyzing the data. However, most of these scenarios accumulate thousands of petabytes in a short period of time, increasing the demand for more storage, and also slowing down speed of data analysis. Hence for realtime scenarios, e.g., agricultural crop tracking, traffic management, etc., such an approach would be impractical. Moreover, depending on the context in which the data is generated and is to be used, only a fraction of the data would be needed for analysis. Therefore, the challenges are to determine which data to keep and which to discard for both short term and long term usage, and define the contextual parameters along which this filtering is to be done. Hence one key problem addressed in this paper is how to define what data the user needs so that filtering algorithms can be defined to extract the data needed. To that end, in this paper, we present a goal driven, context-aware data filtering, transforming and integration approach for loT-based systems. We propose a data warehouse-based data model for specifying the data needed at particular levels of granularity and frequency, that drive data storage and representation (aligned with the Semantic Sensor Network ontology). Throughout our paper, we illustrate our ideas via a realistic running example in the smart city domain, with emphasis on traffic management, and also present a proof of concept prototype.
\end{abstract}

\section{Disciplines}

Engineering | Science and Technology Studies

\section{Publication Details}

Narendra, N. C., Ponnalagu, K., Tamilselvam, S. \& Ghose, A. (2015). Goal-driven context-aware data filtering in loT-based systems. Proceedings - 2015 IEEE 18th International Conference on Intelligent Transportation Systems (pp. 2172-2179). United States: IEEE. 


\section{The Imperative of Government Transparency in Crisis Communication: The Case of AirAsia QZ8501 Crash}

\author{
Uuf Brajawidagda \\ Batam Polytechnic, Indonesia \\ School of Information Systems and \\ Technology \\ University of Wollongong, Australia \\ ub976@uowmail.edu.au
}

\author{
Akemi Takeoka Chatfield \\ School of Information Systems and \\ Technology \\ University of Wollongong, Australia \\ akemi@uow.edu.au
}

\author{
Christopher G. Reddick \\ Department of Public Administration \\ College of Public Policy \\ The University of Texas San Antonio, \\ Texas, USA \\ chris.reddick@utsa.edu
}

\begin{abstract}
This paper examines the role of government transparency in crisis communication in influencing national and/or international public opinions during an enfolding aviation disaster. Using case study research on the 2014 AirAsia QZ8501 crash, we addressed the research question: How does government transparency in crisis communication influence national public opinions? We examined 1,896 newspaper articles from December 28, 2014 to January 14, 2015. Of these articles, we specifically conducted content analysis on 328 articles published during December 28-30, 2014 that cited government organization as their information source. From our content analysis several key themes surfaced to shed some light on the role of government transparency in crisis communication. Based on evidence, we proposed a model of government transparency in crisis communication as influenced by government leadership and search and rescue process openness; information quality, search and rescue structure and information and communication technologies use may also moderate the model's key relationships.
\end{abstract}

\section{Categories and Subject Descriptors}

J.4. [Computer Applications]: Social and Behavioral Sciences Communication. J.1 [Computer Applications]: Administrative Data Processing - government. H.4 [Information Systems]: Information Systems. H.1.1 [Systems and Information]: Value of information

\section{General Terms}

Management, Performance, Human Factors.

\section{Keywords}

Government transparency, crisis communication, AirAsia QZ8501 Crash

Permission to make digital or hard copies of all or part of this work for personal or classroom use is granted without fee provided that copies are not made or distributed for profit or commercial advantage and that copies bear this notice and the full citation on the first page. Copyrights for components of this work owned by others than ACM must be honored. Abstracting with credit is permitted. To copy otherwise, or republish, to post on servers or to redistribute to lists, requires prior specific permission and/or a fee. Request permissions from Permissions@acm.org. dg.o 2015, May 27-30, 2015, Phoenix, AZ, USA. (c) 2015 ACM. ISBN 978-1-4503-3600-0/15/05 ...\$15.00 DOI: http://dx.doi.org/10.1145/2757401.2757423

\section{INTRODUCTION}

In the disaster management literature, crisis communication is critical for the most effective response to enfolding crises. In the digital age, it is critically important for citizens to get up-to-date information on an enfolding crisis. If government does not provide this information, citizens may discount or distrust government and attempt to get it from other sources, such as social media and online news media. How government creates better transparency in crisis communication is critically important for government legitimacy and citizens' trust in government, but relatively unknown, especially given advances in the Internet and the explosive use of social media platforms in society worldwide. This paper examines role of government transparency in crisis communication in influencing national and/or international public opinions during an enfolding aviation disaster. We employ case study research on crisis communication during the AirAsia QZ8501 crash on December 28, 2014. On that day the AirAsia flight QZ8501 from Surabaya (Indonesia) to Singapore suddenly went missing without a trace from Jakarta Air Traffic Control (ATC) radar.

The U.S. Federal Aviation Administration lists Indonesia as one of six countries in Category 2, which fail a safety assessment based on International Civil Aviation Organization (ICAO) requirements [21]. Similarly, the European authorities banned a long list of Indonesian airlines from flying to Europe due to safety concerns [19]. However, Indonesian government has recently been recognized for its speed and efficiency in search and rescue (SAR) operations mounted in the immediate aftermath of the crash of AirAsia QZ8501 and for its transparency in crisis communication targeted for those affected families and for the world audience. This is in stark contrast to its counterpart, Malaysian government, during its 2014 crisis communication of the Malaysian aviation disasters [5, 8, 44].

There have been studies on corporate crisis communication $[6,16$, 52], government crisis communication during natural disasters, such as the 2005 Hurricane Katrina [24] and the 2008 Sichuan earthquake [13], and factors influencing government transparency in non-crisis situations has been examined [7, 9, 11, 22, 35, 47]. However, there is little research investigating the potential role of government transparency in crisis communication in influencing national and/or international public opinions during an enfolding aviation disaster. Therefore, this study aims to reduce this knowledge gap in the literature by addressing a central research question: How does government transparency in crisis communication influence national public opinions? 
The reminder of this paper is structured as follows: in Section 2 we present our literature review on crisis communication and government transparency. Section 3 presents our research methodology. We briefly describe the case of AirAsia QZ8501 in Section 4. In Section 5 we present our findings: events timeline, information sources and factors influencing government transparency in crisis communication. After presenting our discussion in Section 6, Section 7 provides the conclusion of this study.

\section{LITERATURE REVIEW}

\subsection{Crisis Communication}

The literature on crisis communication has investigated corporate crisis situations and corporate strategy for image repair discourse from a public relations point of view [6], corporate crisis communication strategies to protect reputational assets from a situational crisis communication theory perspective [16], and the enhanced effectiveness of corporate crisis communication through insights learned from an expert panel on best practices [52]. In general, much of the literature on corporate crisis communication has used case study research [15] to study the relationship between corporate crisis communication and reputational impacts. Earlier studies have been largely silent about the underlying medium for facilitating or hindering the effectiveness of corporate crisis communication [52]. More recently the corporate use of the Internet [61] and Twitter and blogs [51] represent a new crisis communication media. One of the key challenges in corporate crisis communication lies in the complexity and ambiguity of corporate crises, permitting the corporation to create multiple interpretations of causation and responsibility [64]. For example, in the case of Fukushima Daiichi nuclear disaster, caused by the 2011 Great East Japan earthquake, Utz et al. [66] found that Twitter as the communication medium, crisis type and emotions influenced public reactions to the disaster. Finally, the importance of transparency in corporate crisis communication has not been explicitly understood.

In contrast, the poor government communication on SARS has resulted in the lost public trust in the Hong Kong government [39]. Furthermore, the weaknesses in government communication networks among government agencies have been found in the immediate aftermath of the 2001 9/11 terrorist attack on the World Trade Center [25]. Similarly, neither the U.S. government crisis communication during the 2005 Hurricane Katrina [24] nor the Chinese government crisis communication during the 2008 Sichuan earthquake [13] seemed to have focused on the importance of transparent crisis communication. Of the challenges faced in government crisis communication include process openness and information quality (timeliness, availability, credibility), confidence building and image retaining [13, 52].

More recently, however, in the aftermath of the disappearance of Malaysian Airlines Flight MH370 en route from Kuala Lumpur to Beijing on March 8, 2014, the lack of Malaysian government transparency has drawn heavy criticism. Government failed to meet the transparent information demanded by the families of passengers on board, since they were kept in dark on the progress and outcomes of the search and rescue operations of the lost aircraft. Nearly 3 months after the aviation disaster, Malaysian government finally released reams of raw satellite data used in its much criticized investigation [10].

\subsection{Government Transparency}

While there are different definitions of government transparency, we can define the concept from a citizen's perspective and from a government's perspective. From a citizen's perspective, Piotrowski and Van Ryzin [45, p.308] offer a definition of government transparency as "the ability to find out what is going on inside a public sector organization through avenues such as open meetings, access to records, the proactive posting of information on Web sites, whistle-blower protections, and even illegally leaked information". In contrast, from a government perspective, the Open Government Directive [65, p.1] views government transparency as "providing information to the public on what is government doing". These two definitions share commonality on efficacy and political will of government to share government-owned information with its citizens and other stakeholders. In other words, government agencies need to be able and willing to share government activities, processes, challenges and performance to its stakeholders [11, 36].

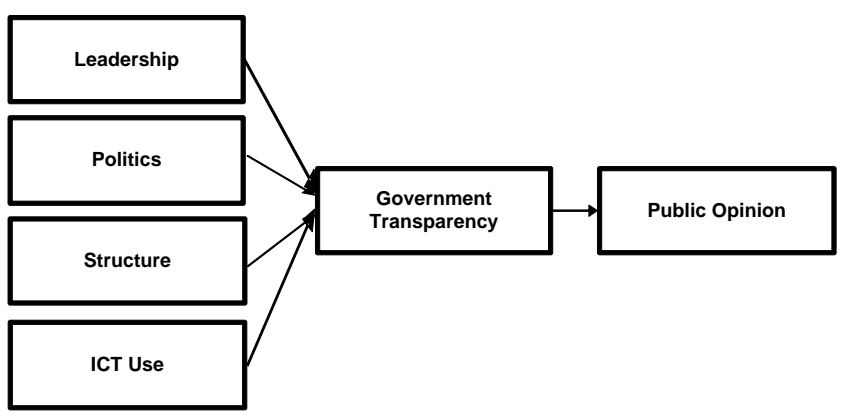

Figure 1. Non-crisis government transparency model

Previous studies have identified factors that influence government transparency in non-crisis situations including: leadership, structure, politics and the use of ICT [7, 9, 11, 22, 35, 47]. Government leadership was referred to the influence of political leaders at national, local or agencies level in guiding the organization to promote transparency [7, 22, 23]. In general, leadership influences the level of transparency in agencies both in direct or indirect way [22, 23]. Ganapati and Reddick [23] found that transparency at the national level indirectly influences the level of transparency in agencies at the state level [23]. Similarly, leader's expectation on transparency will directly set the tone of transparency in an agency $[11,22]$. However, a government initiative, including transparency, requires political support to ensure success [7, 22]. Research shows that political support enhances organizational decisions on transparency [26]. Structure describes the relationships of different units in an organization to establish transparency. The organization's structure also influenced the degree of transparency because it determines how easy a person in the organization can get access to the information [22]. ICT use is the degree to which digital technologies are used to promote transparency. In e-government literature, there have been studies focusing on the role of ICTs in increasing government transparency in many ways including providing wider access and attracting civic engagement [9, 11, 35]. As a consequence, the level of government transparency determines the collective view of the citizens (or public opinion) towards government performance. This includes public trust and satisfaction with government or active participation to government initiatives [22, 34, 36]. Based on the factors and consequences found in previous studies, government transparency 
in non-crisis situation, therefore, can be conceptually presented in Figure 1.

\section{RESEARCH METHODOLOGY}

This study aims to answer our central research question: How does government transparency in crisis communication influence national public opinions? To answer this question, we employ case study research on crisis communication during the AirAsia QZ8501 crash on December 28, 2014. Case study research is most appropriate to answer how or why research questions [18, 70] because it allows us to capture meaningful real-life events [70].

In this case study research, first, we analyzed 1,896 online news articles with the special coverage of AirAsia QZ8501 crash published by detik.com from December 28, 2014 to January 14, 2015. All articles were automatically collected using a crawler that has been developed to extract news from detik.com. The analysis aimed to identify key events and overall performance of the QZ8501 crisis response.

Second, of the 1,896 articles, we identified the information sources of the 544 articles published from December 28 to December 30, 2014. The selection of the observation period was based on the facts that QZ8501 was declared lost on December 28, 2014 and the first debris was found on December 30, 2014. This was the most critical period, which was characterized by substantial degree of uncertainty because the QZ8501 status was not yet revealed to the public.

Our third step was to conduct content analysis on the articles that cited government organization to identify key themes of the articles. Of the 544 articles published between December 28 and December 30, 2014, there are 328 articles that cited government organization as their information source. By developing the key themes, this study aimed to shed light on the role of government transparency in crisis communication. As mentioned in our literature review, there has been relatively little research on the potential role of government transparency in crisis communication. We slightly adapted factors in non-crisis government transparency model (Figure 1) as key themes to guide our content analysis, namely: government leadership, SAR structure, political support and ICT Use. We followed government leadership's, political support's and ICT use's definitions in noncrisis government transparency model as presented in our literature review. Articles highlight the role of government leaders at national and local levels to promote transparency were classified into the government leadership theme. Political support theme consists of articles that covered statements from politicians on the need for transparency for the Search and Rescue (SAR) operations. ICT use theme includes articles that discuss the use of ICT technologies, such as website, social media or crowdsourcing application, to promote the QZ8501 search and rescue operation transparency. While Structure in non-crisis government transparency focused on focal organization, we defined SAR Structure as the clarity on coordination, tasks allocation and supervision of the search and rescue operations, including interagency or international collaboration. Articles categorized in this theme mainly focused on how agencies formed collaboration structure during SAR operation, including tasks allocation.

An Indonesian $\mathrm{PhD}$ student was assigned to conduct the content analysis. Articles were manually read and classified into the relevant themes. NVivo 10 was used to assist the classification. In doing the content analysis, one article was categorized into only one theme. In case one article consists of two or more themes, we chose one dominant theme that best described the article.

Media content analysis is strategically selected because it allows us to identify who says what, through which channel, to whom, and the effect of the message [38, 40,53], thus enabling us to capture the real life event story that is important to the case study $[37,70]$. Content analysis on newspaper articles has been done in e-government research [69]. The selection of detik.com was also strategic because it was the second most popular online news in Indonesia according to alexa.com [2]. Therefore detik.com reached more audiences that could lead to public opinion development. Moreover, while the first popular online news in Indonesia (according to alexa.com [2]) only provided access to newer articles and prohibit us to reach early articles related to QZ8501 crash, detik.com allows our crawler to gather all of its archival articles in the special coverage of the QZ8501 crash.

\section{THE CASE: AIRASIA QZ8501 Crash}

On December 28, 2014, AirAsia flight QZ8501 from Surabaya (Indonesia) to Singapore suddenly went missing without a trace from Jakarta Air Traffic Control (ATC) radar. The flight was scheduled to depart at 5:20 a.m. Western Indonesia standard time and expected to arrive at 8.30 a.m. Singapore time [59]. The flight carried 155 passengers and 7 crew members on board. Of the passengers, there were 3 Korean, 1 British, 1 Malaysian, 1 Singaporean and 149 Indonesian. Meanwhile, of the 7 crew members, 6 were Indonesian and 1 was French [56].

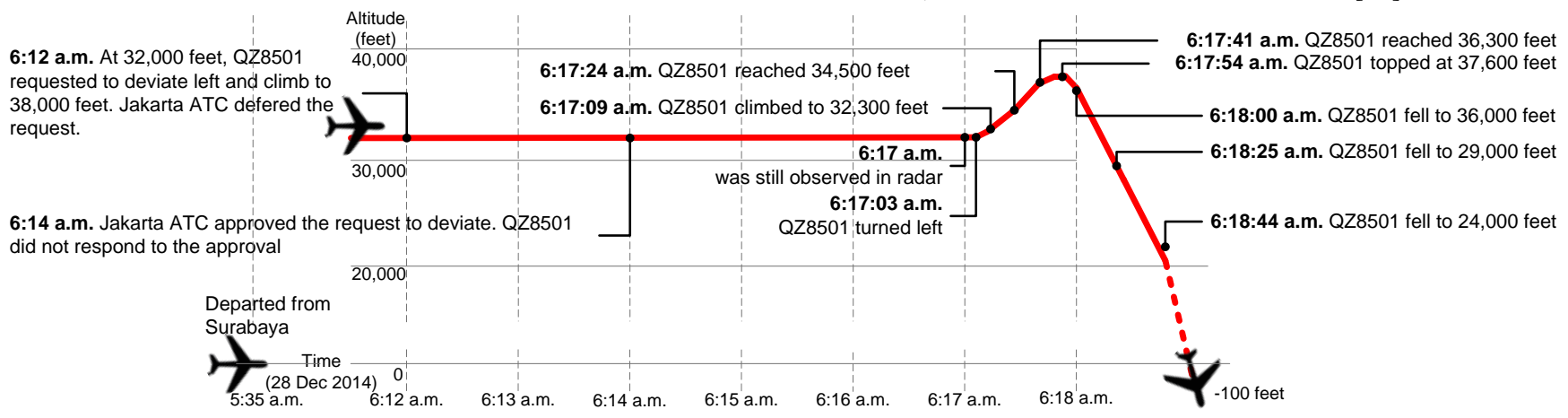

Figure 2. Time series of QZ8501 crash [17, 42]

As shown in Figure 2, against the scheduled flight departure time of 5:20 a.m., the flight actually took off on 5:35 a.m. (or delay of 15 minutes). In Figure 2, while the y-axis shows the altitude (in feet), the $x$-axis presents the time (in minute). There are four horizontal lines in Figure 2 representing the altitude of 0, 20,000, 30,000 and 40,000 feet. The actual altitude of the QZ8501 when 
the aircraft was still monitored by radar is shown in solid red and the dashed red line illustrating the altitude after it fell out of radar.

After 37 minutes cruising, at 6:12 a.m., the pilot sent a request to Jakarta ATC to turn left and climb from its position of 32,000 to 38,000 feet. The Jakarta ATC did not approve the request because at the time there were 7 other flights nearby QZ8501 (where one of them was exactly above the QZ8501) [30]. At 6:14 a.m. Jakarta ATC contacted QZ8501 to inform that they were granted to elevate to 34,000 feet, but QZ8501 did not respond [31]. Three minutes after the Jakarta ATC attempted to contact the aircraft, QZ8501 was still shown at the radar at 6:17 a.m.

At 6:17:03 a.m. QZ8501 deviated to the left side of the path approved by the Jakarta ATC [17, 42]. At 6:17:09, QZ8501 climbed 300 feet to 32,300 feet above sea level. At 6:17:24 a.m., QZ8501 has reached 34,500 feet and continued to climb until 6:17:41 a.m. when it reached 36,300 feet. After reaching its top altitude at 37,600 feet $(6: 17: 54$ a.m.), it then started to rapidly descend. At 6:18:00 a.m., it fell to 36,000 feet. QZ8501 was at 29,000 at 6:18:25 a.m. [62] and the last presence on the radar was at 6:18:44 a.m. with altitude 24,000 [68]. The debris of QZ8501 was found two days later in the shallow water (about 100 feet) in Karimata Strait.

Later on, it was revealed that the request of the QZ8501 deviation at 6:12 a.m. was due to the existence of cumulonimbus cloud cover. Cumulonimbus cloud is vertical cloud associated with thunderstorm and atmospheric instability including lightning and thunder that might be dangerous to aircraft [43, 54, 67]. Cumulonimbus cloud was attributed to the crash of the August 1985 Delta Air Lines L-1011 at the Dallas/Fort Worth Airport [4].

Figure 3 shows a map of the flight path and location of QZ8501's last positions. The actual flight path is shown by solid red line, while the planned flight path is marked by dashed red line. Figure 3 also shows the search area of QZ8501 (bordered by black dash line) which is more than 156 thousand square kilometers and the area where the first debris was found (marked as red rectangle) on December 30, 2014. The Indonesia-led international search and rescue operations involved more than 8 countries, including Indonesia, Russia, Korea, Australia, Malaysia, Singapore, U.S. and China.

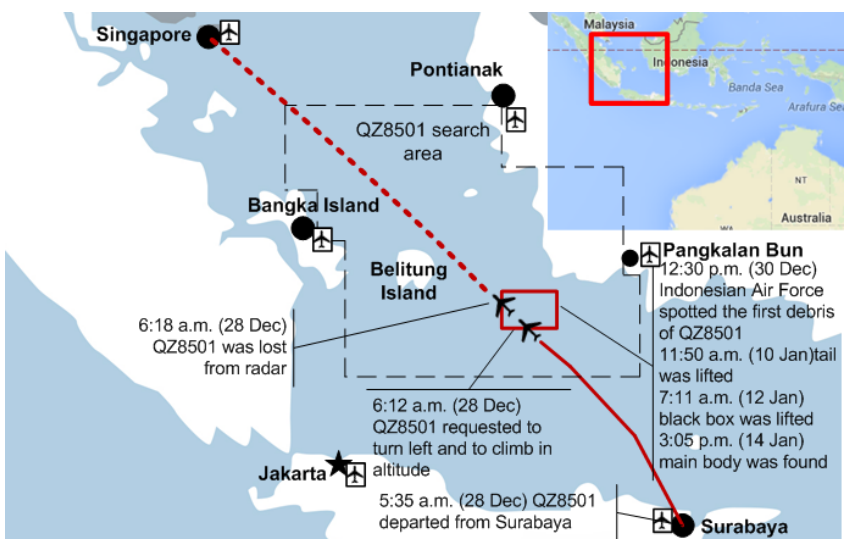

Figure 3. QZ8501 flight path and timeline

\section{RESULTS}

\subsection{Extreme Event Timeline}

Of the 1,896 articles, we draw an extreme event (EE) timeline to develop a clear understanding of the crisis response to the QZ8501 crash. The overall EE timeline is shown in Figure 4. After the QZ8501 last contact at 6:18 a.m. on December 28, 2014, several emergency procedures were undertaken by Jakarta ATC. In aviation, there are international required emergency steps in response to an emergency situation: INCERFA (uncertainty phase), ALERFA (alert phase) and DETRESFA (distress phase) [20]. INCERFA would be declared when ATC could not communicate with an aircraft within 30 minutes. Following INCERFA, ALERFA would be declared when subsequent communication failed to reach the aircraft or there is no further information regarding the aircraft. Finally, when several information inquiries on the aircraft cannot be successfully made and the aircraft can be considered in danger, then DETRESFA would be released. Based on the emergency steps, Jakarta ATC declared QZ8501 as in INCERFA, ALERFA and DETRESFA at 7:08 a.m., 7:28 a.m. and 7:55 a.m., respectively. Since then, QZ8501 status was officially recognized as missing and the search and rescue activities were undertaken. In this case, the INCERFA was released 51 minutes after the last time QZ8501 was shown on radar.

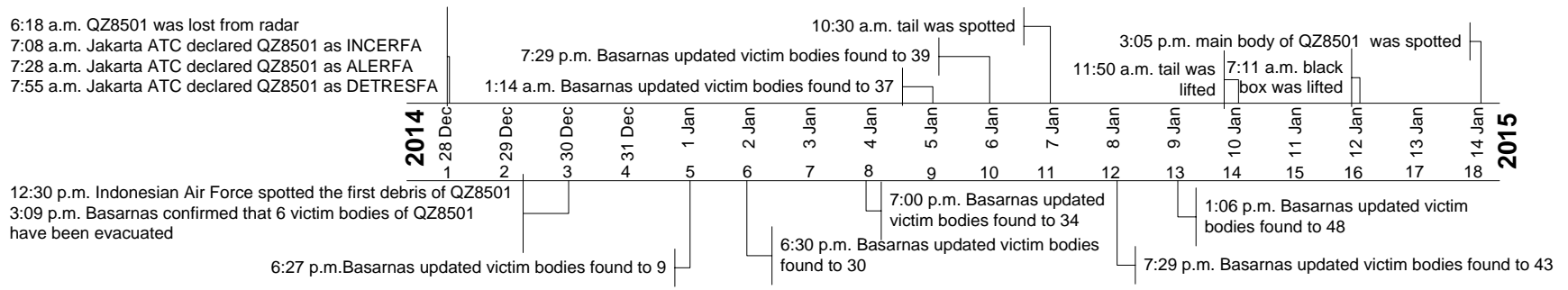

Figure 4. QZ8501 recovery operation events timeline

During the first two days of the search and rescue operations, all of the joint operation parties found nothing that positively identifying bodies and QZ8501 aircraft debris [29]. On the third day, however, the first debris was spotted by the Indonesian Air Force at 12:30 p.m. on December, 282014 [29]. Three hours later, Indonesia's National Search and Rescue Agency (Basarnas) confirmed that 6 bodies were recovered [48]. Later on, the number of bodies found increased to 34 on the eighth day of the search and rescue operations on January 4, 2015 [28]. On $13^{\text {th }}$ day, the number of bodies found reached 48 [33] and remained the same until the end of the observation period on January 14, 2014. All of the bodies-found announcements were carried out by Basarnas, whose main mission is to search, locate and evacuate all of the victims of an emergency or disaster event [12]. The location of the bodies was distributed across the sea in the surrounding area in which the debris of the airplane was found (red rectangle in Figure 3). Meanwhile, the efforts to find the main body of the QZ8501 continued since the first day of the operations. On the 
$11^{\text {th }}$ day after the QZ8501 crash, the tail of the airplane was found and lifted four days later [46]. This was a significant discovery since the tail section contained the black box, which automatically records all the aircraft functions, movements and operations. This was also a step closer to locate the main body of the aircraft, where all the remaining victim bodies might or might not be trapped. The challenge faced by the rescuers was the bad weather and the fast current at the bottom of the sea [50]. On the $16^{\text {th }}$ day of the search and rescue operation, black box was found and successfully lifted. Finally, on the $18^{\text {th }}$ day of the operation, the Singapore Air Force spotted the main body location. Overall, while the Jakarta ATC did not meet the 30 minutes time as required to release INCERFA, the search and rescue operation was considerably fast and transparent [5, 8, 44].

\subsection{Primary Information Sources}

Before we conducted our content analysis, we identified the information source of the 544 articles. The result of this step is presented in Figure 5. In Figure 5, we categorized primary information sources into: central government, disaster management agencies, local government, aviation authority, victim's family, foreign countries, AirAsia and others. Central government consists of president, vice president and some ministries related to the events. For local government, there are two provinces found in this content analysis: East Java and Babel (stands for Bangka Belitung) province. QZ8501 departed from Surabaya which lies in East Java Province and its last position was in the Babel Province area. In Disaster Management Agencies, there are the search and rescue agencies (head office and its regional offices), the National Transportation Safety Committee, Agency for Meteorology, Climatology and Geophysics, Indonesian National Armed Forces (including Army, Navy and Air Force), Indonesian National Police (including province level police in Babel, East Java and Central Kalimantan) the Agency for Assessment and Application of Technology (BPPT) and the National Institute of Aeronautics and Space (LAPAN). In the Aviation Authority, we put Ministry of Transportation, Air Navigation (which is responsible for Air Traffic Controller - ATC) and Airport Authority. Even though the Ministry of Transportation can be grouped either in central government or disaster management agencies, we placed it in the aviation authority group to provide a more accurate classification. In the victim's family, we further categorized into crews' family and passengers' family. For AirAsia, the main information sources were its chairman (Tony Fernandez) and Indonesia AirAsia. Other countries cited in the dataset were Korea, British, Russia, Australia, Singapore, Philippines, and the United States.

In Figure 5, each box represents information sources. For each information source (in the left), we provided the number of the articles found on the online news website (in the right) that cited the corresponding information sources. The total number of articles cited in each category was put in parenthesis following the group title. In total, we found 438 citations in 544 articles. Some articles reported the situation of the QZ8501 search and rescue operation without information source, thus we did not group these articles. In Figure 5, the groups with light grey shadow consist of non-Indonesia government entities.

Of the information source in the government groups, disaster management agencies groups had the most citations, 188 . Within disaster management agencies, the National SAR (74), Indonesian Air Force (32) and Indonesian Navy (31) were the top three cited. Meanwhile other sources were cited less than or equal to ten.
Following that, central government had the second most citations, 59. Only president (16) and vice president (24) have more than ten citations. Aviation authority has 57 citations with the Ministry of Transportation (29) and Airport Authority (21) has been cited the most. Meanwhile AirNav was only cited by 7 articles. In local government, East Java (11) and Babel (10) province share almost the same citations. In total, Indonesia government groups account for 328 citations (or $73 \%$ of the total information source).

Of the non-Indonesia government information sources, victim's family has been cited by 52 articles. Following that, AirAsia, others and foreign countries were cited by 27, 21 and 19 articles, respectively.

\begin{tabular}{|c|c|c|c|}
\hline \multicolumn{2}{|l|}{ Central Government (59) } & \multicolumn{2}{|l|}{ Disaster Management Agencies (191) } \\
\hline President & 16 & The National SAR & 74 \\
\hline Vice President & 24 & SAR Jakarta & 2 \\
\hline Coordinating Minister for & 7 & SAR Babel & 2 \\
\hline Maritim Affairs & & SAR Pontianak & 1 \\
\hline $\begin{array}{l}\text { Coordinating Minister for } \\
\text { Legal, Politics and Security }\end{array}$ & 3 & SAR Surabaya & 2 \\
\hline $\begin{array}{l}\text { Coordinating Minister for } \\
\text { Economics Affair }\end{array}$ & 1 & The National Transportation Safety Committee & 7 \\
\hline Ministry of Foreign Affairs & 5 & Agency for Meteorology, Climatology and & 7 \\
\hline Ministry of Interior Affairs & 1 & Geophysics & \\
\hline Secretary of the Cabinet & 2 & & \\
\hline \multicolumn{2}{|l|}{ Local Government (21) } & Indonesian National Armed Forces & 6 \\
\hline East Java Province & 11 & Indonesian Army & 1 \\
\hline Babel Province & 10 & Indonesian Navy & 31 \\
\hline \multicolumn{2}{|l|}{ Aviation Authority (57) } & & \\
\hline Ministry of Transportation & 29 & Indonesian National Police & 5 \\
\hline Air Navigation & 7 & Babel Police & 10 \\
\hline Airport Authority & 21 & East Java Police & 6 \\
\hline \multicolumn{2}{|l|}{ Victim's Family (52) } & Central Kalimantan Police & 1 \\
\hline Crews' Family & 18 & BPPT & 1 \\
\hline Passengers' Family & 34 & LAPAN & 3 \\
\hline \multicolumn{2}{|l|}{ AirAsia (27) } & \multicolumn{2}{|l|}{ Foreign Countries (19) } \\
\hline Chairman of Air Asia Group & 17 & Korea & 1 \\
\hline Indonesia Air Asia & 10 & British & 1 \\
\hline \multicolumn{2}{|l|}{ Others (21) } & Rusia & 1 \\
\hline "Expert" Observers & 18 & Australia & 5 \\
\hline Malaysia Airline & 1 & Singapore & 7 \\
\hline Virgin Group & 1 & Philippine & 1 \\
\hline Airline Association & 1 & U.S & 3 \\
\hline
\end{tabular}

Figure 5. Primary Information sources

\subsection{Factors Influencing Government Transparency in Crisis Communication}

Based on the 328 articles that cited government organization as their information sources, we conducted content analysis. As explained in the research methodology section, we used factors adapted from non-crisis government transparency as themes for content analysis. The result of the content analysis is presented in Figure 6. In Figure 6, each label consists of information on the theme name and percentage of the number of articles.

Overall, among factors in non-crisis government transparency model, we did not find articles related to Political Support. In contrast, we found two key themes namely Process Openness and Information Quality that were identified based on the crisis communication literature [13]. Information quality refers to the effort to make the information accurate, reliable and timely. This mainly includes articles on the information management and how rumors were handled. Process openness is defined as the provision of information on the search and rescue activities, including performance and challenge. This includes articles on detail SAR operations from first responders, spokespersons or head of agencies. 


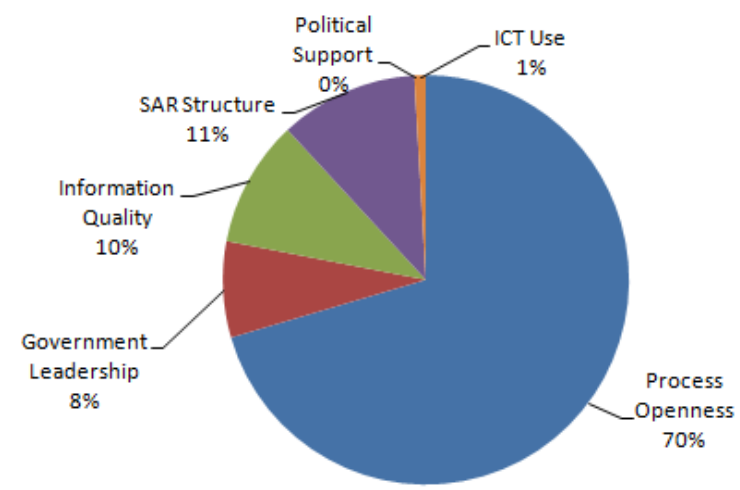

Figure 6. Content analysis results

As in Figure 6, the result shows that Process Openness dominated the content analysis in 231 articles (70\%) out of the total 328 articles. SAR Structure was found in 36 articles (11\%). Next, Information Quality was found in 33 articles (10\%). Government Leadership showed up in 25 articles (8\%) at the fifth place. Rather surprisingly, since the modern search and rescue operations heavily rely on technologies, ICT Use was found only in 3 articles (1\%) in this study. As mentioned before, there was no article on Political Support.

\section{DISCUSSION}

This study investigated a central research question: How does government transparency in crisis communication influence national public opinions? Based on the non-crisis government transparency model (Figure 1) and our content analysis results, we proposed our tentative model on government transparency in crisis communication as shown in Figure 7. Relationships among factors were redefined based on the evidence found in our content analysis.

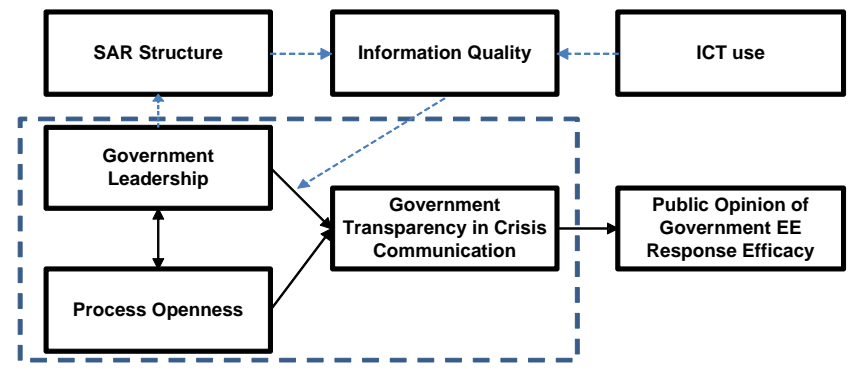

Figure 7. Tentative model on government transparency in crisis communication

While we have provided definitions of Government Leadership, ICT Use, SAR Structure, Information Quality and Process Openness in the previous section, we define government transparency in crisis communication as the government's capability and readiness to provide information to meet citizens' informational demands. This transparency will influence the Public Opinion of Government Emergency Event (EE) Response Efficacy, which we defined as collective views, perception and judgments on the action taken by government agencies during an emergency event. In Figure 7, the dashed rectangle shows the core concept of the government transparency in crisis communication. While the black solid arrow represents strong causality, blue dashed arrow represents weak causality. The relationships among the themes will be discussed in these following sub sections.

\subsection{Government Leadership}

There were 25 (or 8\%) articles that supported the Government Leadership theme. In this study, government leadership was found at the national, agency or local levels during the QZ8501 search and rescue operation. At the national level, for example, on December 28, 2014, President Joko Widodo immediately commissioned the Transportation Minister, Ignasius Jonan, to continuously provide search and rescue progress briefings to all passengers' and crews' families [27]. Similarly, vice president Jusuf Kalla also set the same transparency tone when he met the passengers' family "I asked Basarnas to continuously update the information. If necessary, put it online. If possible, the updates can be made from Jakarta, Tanjungpinang, or from here (Surabaya). If it is also possible, make the pilot's (of the SAR crew) conversation available here during the search and rescue operation" [60].

At the local government level, the East Java governor stated "I want the search results published and nothing was covered up"[55]. At the agency level, the command from the president was responded. For example, the Transportation Minister promised that they will update the information hourly [57]. In response to the vice president transparency tone, information was also provided from airline pilots and crew members who aided and cooperated with the operations. On the third day of the operations, Major Akal Juang, an Indonesian Air Force pilot, was showing the SAR operation process openness by explaining their search route from the cockpit of a Hercules: “(we will) go through Cempedak Island, then we head to the west to Pangkalan Bun, head to the south to Kumai Bay, then to the south to Tanjung Putting, then go along the edge to the west on 1500 feet”. [49, p.1].

This result shows that the clear commission of specific government agencies by the national, agency and local government leaders during the enfolding crisis does seem to influence them in sharing and releasing the government-owned information to the public. In other words, government transparency in crisis communication requires strong government leadership. This result is similar with the previous studies, which find that leadership matters on transparent crisis communication $[11,22,35]$.

\subsection{Process Openness}

Maintaining process openness is one of challenges during crisis [13]. Of the 328 articles, this theme accounts the most articles with 231 articles or $70 \%$. This domination indicated that this theme matters on the government transparency in crisis communication. Process openness was achieved by providing continuous information on the QZ8501 search and process activities through several channels, including head of agencies, spokespersons and first responders. Process openness includes providing information related to the process, challenges faced and performance of the QZ8501 search and rescue operation.

As shown in the Government Leadership example, the QZ8501 search and rescue operation process were opened to the public. Public had access to the detail information such as the route of an aircraft involved in the operation. Not only that, the public was also informed with the challenges faced by the team and the performance they achieved. The National Search and Rescue Agency honestly admitted that they faced challenges including limited information and bad weather. While limited information usually dealt with technological issue, e.g., the case of Emergency 
Locator Transmitter (ELT) filed to work, the team also faced bad weather in the searching area, as stated by the head of the National Search and Rescue Agency "The first challenge is weather. Bad weather affected the search and rescue process" [32].

\subsection{Information Quality}

Providing high quality information during crisis is a challenge for agencies during crisis situation [13]. We found 33 articles (or $10 \%$ ) that supported this theme. To maintain information accuracy, reliability and timeliness, on December 28, 2014, the Head of the National Search and Rescue Agency announced that his Office in Jakarta would serve as the Crisis Information Center for the QZ8501 search and rescue operations at the national government level. The Basarnas Crisis Information Center coordinated with other crisis information centers that were also established by other agencies such as the Indonesian Air Force and the Indonesian Navy. In addition, there was another crisis information center at the Surabaya Airport where the families of the passengers demanded information from government. This new coordination authority and legitimacy of the Basarnas Crisis Information Center was strengthened by the vice president who clearly signaled that Basarnas (or the National Search and Rescue (SAR) agency) was the lead coordinator for the coalition of search and rescue operations involving other nations.

The immediate establishment of the Crisis Information Center has given Basarnas government authority and legitimacy to gain access to extant diverse information sources, including not only other Indonesian government agencies but also overseas governments cooperated in the Indonesia-led search and rescue operations. Among the main tasks performed by the Basarnas Crisis Information Center we found in our content analysis include the importance of collecting all relevant information from all parties involved in the search and rescue operations, releasing the progress briefings on the search and rescue operations, clarifying false information, and finally providing information promptly to specific inquiries on the crash event, especially from the families who were affected by the QZ8501 crash.

Of these four tasks of the Crisis Information Center, clarifying false information was challenging because of the limited information available during the crisis [1, 14]. During the first three days of the search and rescue operations, at least there were 6 misleading false information accounts that needed to be clarified by the Basarnas Crisis Information Center: 1) rumor that QZ8501 had an emergency landing at the eastern part of Belitung Island (see Figure 3); 2) rumor that QZ8501 debris has been found on earlier dates; 3) rumor that QZ8501 has been safely landing at Tacloban, Philippine; 4) rumor that QZ8501 overshot the runway but all the passengers are safe; 5) cyber crime attempts that put CNN logo with an image of an AirAsia aircraft that link to the scam of paid SMS service; 6) rumor that QZ8501 crashed in Batam island (40 minutes from Singapore by ferry); and 7) rumor based on a blog from China that posted an article two weeks before QZ8501 crash and provided prediction that AirAsia was targeted by a group called "black hand". In recent years, rumors have been easily spread through social media which largely generate negative effects and needs the government authorities to provide immediate clarification [1, 14].

All in all, these results showed that Information Quality did not directly relate to the government transparency in crisis communication. Rather, we offered the moderation effect of the information quality on the relationship between government leadership with government transparency in crisis communication. Our result suggested that the existence of the Crisis Information Center amplify the effect of the government leadership tone on transparency.

\subsection{SAR Structure}

Among the main tasks of the National Search and Rescue Agency (Basarnas) are coordination with other agencies search and rescue operations and foreign countries SAR agencies [41]. The QZ8501 search and rescue operations that involved more than thirty agencies from eight countries, including Indonesia, Russia, Korea, Australia, Malaysia, Singapore, U.S. and China required clear coordination structure. Even though in Figure 5 the National Search and Rescue Agency dominated the information source and there were 36 articles (or 11\%) that supported this theme, we did not have clear evidence that SAR structure is directly related to the government transparency in crisis communication.

However, we found that SAR structure influences the information quality by providing more clear information flow. The roles of the National Search and Rescue Agency which lead the QZ8051 search and rescue operation enabled the agency to have wider access to information. Other agencies in Indonesia supported the National Search and Rescue Agency role as the search and rescue operation leader. For example, the National Police ordered its province-level subsidiary organizations to directly coordinate with the National Search and Rescue Agency and Ministry of Transportation as stated by the National Police spokesperson: “(It) has been coordinated with all the Province Level Polices that their area lied in the QZ8501 path to coordinate with Basarnas” [3]. For international aid, the role of the National Search and Rescue Agency in the SAR structure was clear as the Head of the National Search and Rescue Agency stated: "Our post in Pangkal Pinang (in Bangka Island, see Figure 3) will coordinate the search operation undertaken by our neighbors' aircrafts: Malaysia, Singapore and Australia” [63]. The term coordination implies the requirement of swift information flow, which affects information quality.

The structure also affects information quality by increasing the accuracy but decreasing the timeliness at the same time. For example, when the first debris was spotted and some of the family members found the information on the internet, the head of SAR Surabaya held the information from the passengers' family to wait until confirmation from the National Search and Rescue Agency: "we have not passed the information on the debris found in Karimata Strait to the family members. We wait the official information from the National SAR about the findings" [58].

\subsection{ICT Use}

Of the 328 articles, only 3 articles showed the ICT use during the QZ8501 search and rescue operation. Although the number of articles was considerably small, however, we argued that this small number was caused by the nature of our study that chose online news media as the research avenue. Of the examples in the ICT Use was the Basarnas's tweet posted at 10:00 a.m. on December 30, 2014. This tweet attracted 118 retweets and 22 users declared this tweet as their favorite. The tweet was about the description on how the ELT signal works, as stated: "Good morning, to make it clear, this is how the ELT works and sends the distress signal to LUT". The tweet contained a picture explaining SAR satellite system overview. 
The example tweet, however, did not explain the effect of ICT use in government transparency in crisis communication. The evidence of the implication of the ICT use on government transparency in crisis communication was found in another article that was categorized in the Government Leadership theme. The article showed the statement of the vice president as follows "I asked Basarnas to continuously update the information. If necessary, put it online. If possible, the updates can be made from Jakarta, Tanjungpinang, or from here (Surabaya). If it is also possible, make the pilot's (of the SAR crew) conversation available here during the search and rescue operation" [60]. In this statement, the vice president realized that by providing the information online through the use of ICT, it will create the information of the QZ8501 publicly available. This statement also indicated that the information should be timely, accurate and reliable. In other words, ICT use implies information quality.

\section{CONCLUSIONS}

There has been relatively little research on the potential role of government transparency in crisis communication in influencing national and/or international public opinions during an enfolding aviation disaster. Therefore, this study has investigated a central research question: How does government transparency in crisis communication influence national public opinions?

We examined 1,896 articles published in detik.com from December 28, 2014 to January, 14, 2015. Of these articles, we then identified the information source of the 544 articles published in December 28-30, 2014. Of these 544 articles, we conducted content analysis on the 328 articles that cited government organization as their information source. In this case study, we presented real-life events to preserve meaningful information by providing timeline of the QZ851 crash and the first 14 days of its search and rescue operation [70]. Based on the content analysis, we identified factors that influencing government transparency in crisis communication namely: government leadership, process openness, information quality, SAR structure and ICT use. We proposed our tentative model to explain the relationship among these factors.

Our findings suggested practical and theoretical contributions to the existing research on crisis communication. This study provided a general understanding in crisis management to establish more transparent crisis communication in responding emergency events. Theoretically, our findings offered a model to reduce the gap in the literature.

Our limitations include the examination of a single online news media source. Furthermore, we only examined one case study, and our results may not be applicable to other disasters. Our future research directions include a further inquiry into potential roles of information quality, SAR structure and ICT use as independent variables or moderators of the proposed government transparency in crisis communication model. Future research also extends to Malaysian aviation disasters for comparative case analysis.

\section{REFERENCES}

[1] Acar, A. and Muraki, Y., 2011. Twitter for crisis communication: Lessons learned from Japan's tsunami disaster. International Journal of Web Based Communities 7, 3, 392-402.
[2] Alexa, 2015. Top Sites in Indonesia. http://www.alexa.com/topsites/countries/ID. Accessed: January 21, 2015

[3] Amelia, M., 2014. Polri: Polda Terkait Sudah Koordinasi dengan Basarnas Cari AirAsia (The National Police: The Related Province-Level Polices have been Coordinated with Basarnas to Search AirAsia) http://news.detik.com/read/2014/12/28/134340/2788312/10/ polri-polda-terkait-sudah-koordinasi-dengan-basarnas-cariairasia?n992204fksberita. Accessed: December 30, 2014

[4] Aviation Safety Network, 1985. Accident Description. Aviation Safety Network Database. http://aviationsafety.net/database/record.php?id=19850802-0. Accessed: January 20, 2015

[5] Bachelard, M., 2015. AirAsia flight QZ8501: faces from a lost flightAccessed: January 3, 2015

[6] Benoit, W.L., 1997. Image repair discourse and crisis communication. Public Relations Review 23, 2, 177-186.

[7] Bertot, J.C., Jaeger, P.T., and Grimes, J.M., 2010. Using ICTs to create a culture of transparency: E-government and social media as openness and anti-corruption tools for societies. Government Information Quarterly 27, 3, 264-271. DOI $=$ http://dx.doi.org/http://dx.doi.org/10.1016/j.giq.2010.03.001.

[8] Blake, C., 2014. Indonesia Learns Lessons From MH370 in AirAsia Plane Disaster. http://www.bloomberg.com/news/2014-12-31/indonesialearns-lessons-from-mh370-in-airasia-plane-disaster.html. Accessed: January 7, 2015

[9] Bonsón, E., Torres, L., Royo, S., and Flores, F., 2012. Local e-government 2.0: Social media and corporate transparency in municipalities. Government Information Quarterly 29, 2, 123-132.

[10] CBSN News, 2014. Malaysia Airlines Flight 370: Gov't releases raw satellite data linked to plane's path. http://www.cbsnews.com/news/malaysia-airlines-flight-370govt-releases-raw-satellite-data-linked-to-planes-path/. Accessed: December 30, 2014

[11] Chatfield, A.T. and Brajawidagda, U., 2013. Political will and strategic use of YouTube to advancing government transparency: An analysis of Jakarta government-generated YouTube videos. In Electronic Government, M.A. Wimmer, M. Janssen and H.J. Scholl Eds. Springer, 26-37.

[12] Chatfield, A.T. and Brajawidagda, U., 2013. Twitter early tsunami warning system: A case study in Indonesia's Natural Disaster Management. In System Sciences (HICSS), $46^{\text {th }}$ Hawaii International Conference on IEEE, Hawaii, USA, 2050-2060. DOI= http://dx.doi.org/10.1109/hicss.2013.579.

[13] Chen, N., 2009. Institutionalizing public relations: A case study of Chinese government crisis communication on the 2008 Sichuan earthquake. Public Relations Review 35, 3, 187-198.

[14] Chen, R. and Sakamoto, Y., 2013. Perspective matters: Sharing of crisis information in social media. In System Sciences (HICSS), 2013 46th Hawaii International Conference on IEEE, 2033-2041.

[15] Coombs, W.T., 2007. Attribution theory as a guide for postcrisis communication research. Public Relations Review 33, 2, 135-139.

[16] Coombs, W.T. and Holladay, S.J., 2002. Helping crisis managers protect reputational assets initial tests of the situational crisis communication theory. Management Communication Quarterly 16, 2, 165-186. 
[17] EC Publishing Media, 2015. Jonan Beberkan Detik detik AirAsia QZ8501 Hilang Kontak, Ini Kronologis dan Penyebabnya (Jonan Revealed The Minutes of AirAsia QZ8501 Lost Contact, the Cause and Chronology). https://www.youtube.com/watch?v=CrosPP9NcRg. Accessed: December 2015, 2015

[18] Eisenhardt, K.M., 1989. Building theories from case study research. Academy of Management review 14, 4, 532-550.

[19] European Commission, 2014. Lisf of Air Carriers of Which All Operations are Subject to a Ban within the EU, with Exceptions. http://ec.europa.eu/transport/modes/air/safety/airban/doc/list_en.pdf. Accessed: January 15, 2015

[20] FAA, 2014. Air Traffic Control. https:/www.faa.gov/air traffic/publications/ATpubs/ATC/T OC.html. Accessed: January 15, 2015

[21] FAA, 2014. FAA Flight Standards Service: International Aviation Safety Assessment (IASA) Program. http://www.faa.gov/about/initiatives/iasa/media/iasaws.xlsx. Accessed: January 15, 2015

[22] Fairbanks, J., Plowman, K.D., and Rawlins, B.L., 2007. Transparency in government communication. Journal of Public Affairs 7, 1, 23-37.

[23] Ganapati, S. and Reddick, C.G., 2012. Open e-government in U.S. state governments: Survey evidence from Chief Information Officers. Government Information Quarterly 29, 2, 115-122.

[24] Garnett, J.L. and Kouzmin, A., 2007. Communicating throughout Katrina: Competing and complementary conceptual lenses on crisis communication. Public Administration Review 67, SUPPL. 1, 171-188.

[25] Goel, S., Belardo, S., and Iwan, L., 2004. A resilient network that can operate under duress: to support communication between government agencies during crisis situations. In System Sciences, the 37th Annual Hawaii International Conference on, Hawaii, USA, 11 pp. DOI= http://dx.doi.org/10.1109/hicss.2004.1265312.

[26] Ho, A.T.K. and Ni, A.Y., 2004. Explaining the adoption of e-government features: A case study of Iowa county treasurers' offices. American Review of Public Administration 34, 2, 164-180.

[27] Hutasoit, M., 2014. Perintahkan Aparat All Out, Jokowi Doakan Keselamatan Penumpang dan Kru AirAsia (Order the Apparatus to be All Out, Jokowi Prays the Passengers and AirAsia Crews Safety). http://news.detik.com/read/2014/12/28/142202/2788338/10/ perintahkan-aparat-all-out-jokowi-doakan-keselamatanpenumpang-dan-kru-airasia?n992204fksberita. Accessed: December 28, 2014

[28] Indrawan, A.F., 2014. Basarnas: Total Ada 34 Jenazah yang Telah Ditemukan (Basarnas: In Total There are 34 Victim Bodies

Found). http://news.detik.com/read/2015/01/04/191651/2793663/10/ basarnas-total-ada-34-jenazah-yang-telahditemukan?n992204fksberita. Accessed: January 4, 2015

[29] Ismail, R., 2014. Live Update Pencarian AirAsia QZ8501 Hari Ketiga (Live Update The Search of AirAsia QZ8501 in the Third

Day). http://news.detik.com/read/2014/12/30/065426/2789643/10/1 ive-update-pencarian-airasia-qz8501-hari-ketiga. Accessed: December 31, 2014

[30] Ismailian, T.N., 2014. Ada 7 Pesawat Lain di Dekat QZ8501 yang Hilang, 3 Pesawat Sejalur (There are 7 other Aircrafts near by the lost QZ8501, 3 Aircrafts are in line). http://news.detik.com/read/2014/12/29/160039/2789264/10/ ada-7-pesawat-lain-di-dekat-qz8501-yang-hilang-3-pesawatsejalur?n992204fksberita. Accessed: December 30, 2014

[31] Ismailian, T.N., 2014. ATC Akui Kehilangan Kontak Dengan QZ8501 Sejak Pukul 06.14 WIB (ATC Acknowledged to Lost Contact with QZ8501 since 06.14 Western Indonesia Standard Time). http://news.detik.com/read/2014/12/29/170112/2789327/10/ atc-akui-kehilangan-kontak-dengan-qz8501-sejak-pukul0614-wib?n992204fksberita. Accessed: December 30, 2014

[32] Ismailian, T.N., 2014. Tantangan Berat Basarnas dalam Pencarian Pesawat AirAsia QZ8501 (Basarnas's Big Challenges in Searcing AirAsia QZ8501). http://news.detik.com/read/2014/12/28/181011/2788467/10/t antangan-berat-basarnas-dalam-pencarian-pesawat-airasiaqz8501?n992204fksberita. Accessed: December 30, 2014

[33] Ismailian, T.N., 2015. 48 Jenazah Korban AirAsia QZ8501 Telah Ditemukan (48 Victim Bodies of AirAsia QZ8501 have been Found). http://news.detik.com/read/2015/01/09/130621/2798677/10/ 48-jenazah-korban-airasia-qz8501-telahditemukan?n992204fksberita. Accessed: January 9, 2015

[34] Kim, S., 2010. Public trust in government in Japan and south Korea: Does the rise of critical citizens matter? Public Administration Review 70, 5, 801-810.

[35] Kim, S., Kim, H.J., and Lee, H., 2009. An institutional analysis of an e-government system for anti-corruption: The case of OPEN. Government Information Quarterly 26, 1, 4250.

[36] Kim, S. and Lee, J., 2012. E-Participation, Transparency, and Trust in Local Government. Public Administration Review 72, 6, 819-828.

[37] Kohlbacher, F., 2006. The use of qualitative content analysis in case study research. In Forum Qualitative Sozialforschung/Forum: Qualitative Social Research.

[38] Lasswell, H.D., 1952. The comparative study of symbols: An introduction. Stanford University Press, CA, USA.

[39] Lee, K., 2009. How the Hong Kong government lost the public trust in SARS: Insights for government communication in a health crisis. Public Relations Review 35, 1, 74-76.

[40] Macnamara, J., 2005. Media content analysis: Its uses, benefits and best practice methodology. Asia Pacific Public Relations Journal 6, 1, 1-34.

[41] Ministry of Transportation, 2005. Transportation Minister Rule 432005 on Organization and Organizational Administration.

http://www.basarnas.go.id/index.php/halaman/36/tugas-danfungsi. Accessed: January 15, 2015

[42] Nistanto, R.K., 2015. Kronologi Detik-detik Jatuhnya AirAsia QZ8501 Versi Kemenhub (Ministry of Transportation's Version of the Final Minutes of the Fall of AirAsia QZ8501 Chronology). http://tekno.kompas.com/read/2015/01/26/15552167/Kronol ogi.Detik-detik.Jatuhnya.AirAsia.QZ8501.Versi.Kemenhub. Accessed: January 27, 2015

[43] NOAA, 2011. Cloud Classification and Characteristics. http://www.crh.noaa.gov/lmk/?n=cloud_classification. Accessed: January 20, 2015

[44] Pearson, M., 2014. Despite superficial similarities, AirAsia and MH370 incidents very different. 
http://edition.cnn.com/2014/12/28/world/asia/airasia-mh370differences/. Accessed: January 2, 2015

[45] Piotrowski, S.J. and Van Ryzin, G.G., 2007. Citizen attitudes toward transparency in local government. The American Review of Public Administration 37, 3, 306-323.

[46] Purbaya, A.A., 2015. Akhirnya! Ekor AirAsia QZ8501 Terangkat ke Permukaan (Finally! The Tail of AirAsia QZ8501 was Lifted to the Surface). http://news.detik.com/read/2015/01/10/125855/2799516/10/ akhirnya-ekor-airasia-qz8501-terangkat-kepermukaan?n992204fksberita. Accessed: January 11, 2015

[47] Relly, J.E. and Sabharwal, M., 2009. Perceptions of transparency of government policymaking: A cross-national study. Government Information Quarterly 26, 1, 148-157.

[48] Retaduari, E.A., 2014. 3 dari 6 Mayat Dievakuasi KRI Bung Tomo dari Perairan Pangkalan Bun (3 out of 6 Victim Bodies were Evacuated by KRI Bung Tomo from Pangkalan Bun Sea). http://news.detik.com/read/2014/12/30/150847/2790173/10/ airasia-hilang-kepala-basarnas-ada-lebih-dari-satu-jenazahditemukan?n992204fksberita. Accessed: December 31, 2014

[49] Retaduari, E.A., 2014. Lika-liku Kru Hercules TNI AU Temukan Jasad dan Serpihan AirAsia (The Story of Indonesian Air Force Hercules Crews to Find Victim Bodies and Debris of AirAsia). http://news.detik.com/read/2014/12/30/212224/2790569/10/1 ika-liku-kru-hercules-tni-au-temukan-jasad-dan-serpihanairasia?n992204fksberita. Accessed: December 31, 2014

[50] Retaduari, E.A., 2015. Kecepatan Evakuasi Ekor AirAsia QZ8501 Tergantung pada Cuaca (The Speed of AirAsia QZ8501's Tail Evacuation Depens on the Weather). http://news.detik.com/read/2015/01/08/132450/2797624/10/ kecepatan-evakuasi-ekor-airasia-qz8501-tergantung-padacuaca?n992204fksberita. Accessed: January 8, 2015

[51] Schultz, F., Utz, S., and Göritz, A., 2011. Is the medium the message? Perceptions of and reactions to crisis communication via twitter, blogs and traditional media. Public Relations Review 37, 1, 20-27.

[52] Seeger, M.W., 2006. Best practices in crisis communication: An expert panel process. Journal of Applied Communication Research 34, 3, 232-244.

[53] Shoemaker, P. and Reese, S.D., 1996. Mediating the message. Longman Publishers, White Plains, New York, USA.

[54] Skybrary, $2014 . \quad$ Cumulonimbus. http://www.skybrary.aero/index.php/Cumulonimbus. Accessed: January 20, 2015

[55] Sugiharto, B., 2014. Di Depan Tony Fernandes, Soekarwo Minta Hasil Pencarian AirAsia Tak Ditutupi (In Front of Tony Fernandez, Soekarwo Wanted The Search Result of AirAsia

Open).

http://news.detik.com/read/2014/12/28/210623/2788520/10/ di-depan-tony-fernandes-soekarwo-minta-hasil-pencarianairasia-tak-ditutupi?n992204fksberita. Accessed: December 28, 2014

[56] Sugiharto, B., 2014. Ini Daftar Nama 155 Penumpang AirAsia yang Hilang Kontak (This is the List of The 155 Passengers of the Lost Contact AirAsia). http://news.detik.com/read/2014/12/28/135107/2788314/10/i ni-daftar-nama-155-penumpang-airasia-yang-hilangkontak?n992204fksberita. Accessed: December 29, 2014

[57] Sugiharto, B., 2014. Menhub: SAR Singapura Juga Membantu Pencarian AirAsia (Transportation Minister:
Singapore SAR also Help in Searching AirAsia). http://news.detik.com/read/2014/12/28/132443/2788303/10/ menhub-sar-singapura-juga-membantu-pencarianairasia?n992204fksberita. Accessed: December 30, 2014

[58] Sugiharto, B., 2014. Serpihan Pesawat Ditemukan, Kerabat Penumpang di Bandara Juanda Cemas (Aircraft Debris Found, Passegers' Family in Juanda Airport are Anxious). http://news.detik.com/read/2014/12/30/140743/2790111/10/. Accessed: December 30, 2014

[59] Sutianto, F.D., 2014. Dirut AirNav: Pesawat Hilang di Sebelah Timur Selatan Tanjung Pandan (Director of Airnav: The Aircraft Lost in the South East of Tanjung Pandan)Accessed: December 29, 2014

[60] Taufiqqurrahman, M., 2014. JK Temui Keluarga Penumpang: Tidak Ada Batas Waktu Pencarian AirAsia (JK Met Passengers' Family: There is no Time Limit for the AirAsia Search). http://news.detik.com/read/2014/12/29/161259/2789284/10/j k-temui-keluarga-penumpang-tidak-ada-batas-waktupencarian-airasia?n992204fksberita. Accessed: December 30, 2014

[61] Taylor, M. and Perry, D.C., 2005. Diffusion of traditional and new media tactics in crisis communication. Public Relations Review 31, 2, 209-217.

[62] Tempo, 2015. Data Logbook, Air Asia QZ8501 Kerap Bermasalah (Logbook Data, Air Asia QZ8501 was often in Trouble.

http://www.tempo.co/read/news/2015/01/23/090636951/Dat a-Logbook-Air-Asia-QZ8501-Kerap-Bermasalah. Accessed: January 25, 2015

[63] Triyoga, H., 2014. Pusat Kendali SAR AirAsia QZ 8501 Dipusatkan di Pangkal Pinang (Command Center SAR AirAsia QZ8501 is Centralized in Pangkal Pinang). http://news.detik.com/read/2014/12/28/184144/2788476/10/ pusat-kendali-sar-airasia-qz-8501-dipusatkan-di-pangkalpinang?n992204fksberita. Accessed: December 29, 2014

[64] Ulmer, R.R. and Sellnow, T.L., 2000. Consistent questions of ambiguity in organizational crisis communication: Jack in the Box as a case study. Journal of Business Ethics 25, 2, 143-155.

[65] US Executive Office, 2009. Open Government Directive. http://www.whitehouse.gov/sites/default/files/omb/assets/me moranda_2010/m10-06.pdf. Accessed: July 22, 2014

[66] Utz, S., Schultz, F., and Glocka, S., 2013. Crisis communication online: How medium, crisis type and emotions affected public reactions in the Fukushima Daiichi nuclear disaster. Public Relations Review 39, 1, 40-46.

[67] Wikipedia, 2014. Cumulonimbus Cloud. http://en.wikipedia.org/wiki/Cumulonimbus_cloud. Accessed: January 20, 2015

[68] Wikipedia, 2015. Indonesia AirAsia Flight 8501. http://en.wikipedia.org/wiki/Indonesia_AirAsia_Flight_8501 . Accessed: January 28, 2015

[69] Yildiz, M. and Saylam, A., 2013. E-government discourses: An inductive analysis. Government Information Quarterly 30, 2, 141-153.

[70] Yin, R.K., 2003. Case study research: Design and methods. SAGE Publications, Thousand Oaks, CA. 